\title{
Effects of vitamin $D$ on calcium regulation in vitamin-D-deficient pigs given a phytate-phosphorus diet
}

\author{
By A. POINTILLART AND NICOLE FONTAINE \\ Station de Recherches de Nutrition, INRA, 78350 Jouy-en-Josas, France \\ AND MONIQUE THOMASSET \\ INSERM, Unité 120, 78110 Le Vesinet, France
}

(Received 23 January 1986 - Accepted 26 June 1986)

1. Vitamin-D-deficient pigs were fed on a phytate-phosphorus diet and treated with vitamin $\mathrm{D}_{3}(+\mathrm{D})$ to examine the time-course of adaptative changes in plasma minerals, vitamin D metabolites, parathyroid hormone (PTH) and calcium balance and intestinal $\mathrm{Ca}$-binding protein (CaBP).

2. The 5-week vitamin D repletion ( $25 \mu \mathrm{g}$ cholecalciferol $/ \mathrm{kg}$ diet) regimen restored plasma $\mathrm{Ca}, \mathrm{P}$ and alkaline phosphatase (EC 3.1.3.1) to normal, decreased PTH and markedly and rapidly increased plasma 25hydroxycholecalciferol (25-OHD, sevenfold after $4 \mathrm{~d}$ ) and 1,25-dihydroxycholecalciferol $\left(1,25(\mathrm{OH})_{2} \mathrm{D}_{3}, 1 \cdot 8\right.$-fold after $4 \mathrm{~d}$ ).

3. CaBP concentrations were markedly elevated all along the digestive tract, especially in the distal regions.

4. Ca absorption and retention were enhanced (fourfold and sixfold respectively) by the $+\mathrm{D}$ diet.

5. The improved $\mathrm{Ca}$ absorption, coupled with increased $\mathrm{CaBP}$ and $1,25(\mathrm{OH})_{2} \mathrm{D}_{3}$ levels, suggest that vitamin $\mathrm{D}$ metabolism in phytate-P-fed pigs is sensitive to the depressed Ca availability due to phytate feeding. It also indicates that $\mathrm{CaBP}$ may play an important role in the adaptation of $\mathrm{Ca}$ absorption.

6. Persistent hypercalciuria indicates that mineral metabolism was still affected by the phytate nature of the dietary $P$ in spite of the vitamin $D$ treatment.

Phosphorus depletion induces increases in circulating 1,25-dihydroxycholecalciferol $\left(1,25(\mathrm{OH})_{2} \mathrm{D}_{3}\right.$ ), intestinal calcium-binding protein $(\mathrm{CaBP})$ and $\mathrm{Ca}$ absorption (for review, see Sommerville et al. 1985 b). Phytate-P, which is the predominant P source in pig feeds, leads to $P$ deficiency if no additional inorganic $P$ is provided (Pointillart et al. 1984, 1985), and phytate-P absorption is improved by vitamin D supplementation (Fontaine $e$ t al. 1985) demonstrating the importance of this form of $\mathrm{P}$ for pig husbandry. Diets in which the bulk of the phosphate is in the form of phytate also give rise to major disturbances of $\mathrm{Ca}$ metabolism (hypocalcaemia, hypercalciuria) and cause significant reductions in the utilization of $\mathrm{Ca}$ by the formation of poorly absorbed insoluble Ca phytate (Pointillart et al. 1985). These disturbances are aggravated by vitamin D deficiency (Pointillart et al. 1985). In the present study, we have used vitamin-D-deficient pigs to examine the capacity of vitamin $\mathrm{D}$ repletion to overcome the disturbances of $\mathrm{Ca}$ metabolism caused by consumption of a diet whose phosphate content, while normal, is largely $(80 \%)$ in the form of phytate.

We have also examined the changes in the principal plasma variables linked to plasma phosphate and $\mathrm{Ca}$ regulation, 25-hydroxycholecalciferol $(25-\mathrm{OHD}), 1,25(\mathrm{OH})_{2} \mathrm{D}_{3}$, alkaline phosphatase (EC 3.1.3.1; AP) and parathyroid hormone (PTH) levels, throughout the experimental period. They were measured before and during the period of vitamin $D$ supplementation and compared with those of non-supplemented vitamin-D-deficient pigs, At the end of the experimental period the pigs were killed and the CaBP contents of a number of areas of the small intestine were measured to determine what, if any, correlation existed between the values and the $\mathrm{Ca}$ absorption measured immediately before death. 
Table 1. Composition of experimental diets $(\mathrm{g} / \mathrm{kg})$

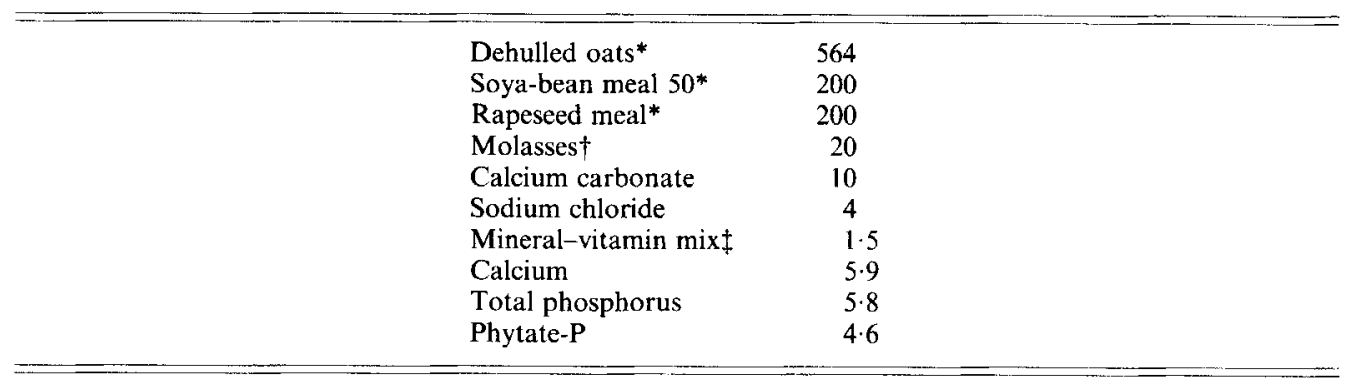

* From INRA (78280 Guyancourt, France).

$\uparrow$ Sugar-beet.

$\ddagger$ Providing (mg/kg diet): $125 \mathrm{Cu}$ as $\mathrm{CUSO}_{4} \cdot 5 \mathrm{H}_{2} \mathrm{O}, 150 \mathrm{Zn}$ as $\mathrm{ZnSO}_{4} \cdot \mathrm{H}_{2} \mathrm{O}, 80 \mathrm{Fe}$ as $\mathrm{FeSO}_{4} \cdot 7 \mathrm{H}_{2} \mathrm{O}, 30 \mathrm{Mn}$ as $\mathrm{MnSO}_{4} \cdot \mathrm{H}_{2} \mathrm{O}, 2 \mathrm{Co}$ as $\mathrm{CoSO}_{4} \cdot 7 \mathrm{H}_{2} \mathrm{O}, 0.6 \mathrm{I}$ as $\mathrm{KI}$; vitamins (/kg diet): vitamin $\mathrm{A} 1500 \mu \mathrm{g}$ as retinyl palmitate, vitamin E $20 \mathrm{mg}$ as $\alpha$-tocopheryl acetate, thiamin $2 \mathrm{mg}$ as thiamin hydrochloride, pyridoxine $10 \mathrm{mg}$ as pyridoxine hydroxide, riboflavin $10 \mathrm{mg}$, ascorbic acid $20 \mathrm{mg}$, cyanocobalamin $50 \mu \mathrm{g}$, Ca pantothenate $40 \mathrm{mg}$, choline chloride $750 \mathrm{mg}$, niacin $20 \mathrm{mg}$, vitamin $\mathrm{D}_{3}$ : no supplementation except $+\mathrm{D}$ group $25 \mu \mathrm{g}$ as cholecalciferol.

\section{MATERIAL AND METHODS}

\section{Animals and diets}

Fourteen newly-weaned 4-week-old Large White pigs, weighing 7 (SE 0.2) $\mathrm{kg}$, were placed in an u.v.-light-free environment and fed on a standard weaning diet for 2 months. This diet, as previously described (Fontaine et al. 1985), contained no vitamin D supplement. The pigs were then placed on the experimental diet (Table 1) for a period of 2 weeks. Neither vitamin $\mathrm{D}$ nor inorganic $\mathrm{P}$ were added to the diet, which contained $6 \mathrm{~g} \mathrm{Ca}$ and $6 \mathrm{~g} \mathrm{P}$ (of which $800 \mathrm{mg} / \mathrm{g}$ was phytate-P) $/ \mathrm{kg}$. At the end of this period the pigs were divided into two groups (seven pigs per group). One group was fed on the experimental diet without vitamin $\mathrm{D}(-\mathrm{D})$ and the other was given the same diet supplemented with $25 \mu \mathrm{g}$ vitamin $\mathrm{D}_{3} / \mathrm{kg}(+\mathrm{D})$. Animals were killed after 5 weeks on these $(+\mathrm{D}$ or $-\mathrm{D})$ diets. Blood samples were taken at time 0 , i.e. when first placed on the experimental diet, and $4 \mathrm{~d}$ and 2 and 5 weeks after the beginning of the vitamin $\mathrm{D}$ supplementation. Thus, the initial 2-week feeding of the unsupplemented diet was the phytate-feeding period and the following 5 week period was the vitamin-D-treatment period.

\section{Measurements}

Intestinal $\mathrm{CaBP}$. At slaughter, segments $(200 \mathrm{~mm})$ of proximal and distal duodenum, distal ileum, mid-jejunum, proximal caecum and colon were excised, everted and washed in cold saline ( $9 \mathrm{~g}$ sodium chloride/l). Mucosal tissue was scraped off in an ice-bath and the CaBP contents determined using a radioimmunoassay employing specific antibodies to purified intestinal pig CaBP as previously described (Pointillart et al. 1984). Maximum sensitivity was $1 \mathrm{ng} \mathrm{CaBP}$ per assay tube. The results were expressed as $\mu \mathrm{g} \mathrm{CaBP} / \mathrm{mg}$ soluble mucosal protein ( $100000 \mathrm{~g}$ supernatant fraction).

Vitamin D metabolites. Plasma vitamin D metabolites, 25-OHD and $1,25(\mathrm{OH})_{2} \mathrm{D}$ were extracted from 1-2 $\mathrm{ml}$ plasma samples and separated by a modification of the method of Adams et al. (1981). This modification consisted of ethanol-diethyl ether-hexane $(2: 5: 2$, by vol.) lipid extraction instead of using methanol-methylene chloride to obtain an upper organic phase. After elution on Sep-Pak cartridge, fraction II (25-OHD) was measured by a competitive protein-binding assay (Preece et al. 1974) and fraction III $\left(1,25(\mathrm{OH})_{2} \mathrm{D}\right)$ subjected to high-performance liquid chromatography (Waters Microporasil column, 
$300 \times 3.9 \mathrm{~mm}$, eluted with hexane-isopropanol $(90: 10, \mathrm{v} / \mathrm{v}$; flow-rate $2 \mathrm{ml} / \mathrm{min})$. The fraction containing $1,25(\mathrm{OH})_{2} \mathrm{D}$ was evaporated under nitrogen and radioimmunoassay performed using the Buhlman Laboratories' ( $\mathrm{CH} 4024$ Basel, Switzerland) kit, based on the method of Bouillon et al. (1977). The sensitivities were 1.25 pmol for $25-O H D$ and $0.01 \mathrm{pmol}$ for $1,25(\mathrm{OH})_{2} \mathrm{D}$ per ml plasma. Variabilities did not exceed $15 \%$ for either assay. As the diet contained vitamin $\mathrm{D}_{3}$ almost exclusively, plasma $25-\mathrm{OHD}$ and $1,25(\mathrm{OH})_{2} \mathrm{D}$ should be considered as 25-hydroxycholecalciferol and 1,25-dihydroxycholecalciferol respectively.

Plasma indices. Plasma Ca was measured by atomic absorption spectrophotometry, phosphate was determined as inorganic P by the method of Chen et al. (1956). Plasma immunoreactive PTH levels were measured with PTH-RIA 200 kits (CEA, ORIS, BP 21 Gif, France) using an antibody directed against the carboxyl terminal of bovine PTH. The lower limit of detectability was $0.37 \mu \mathrm{g} / 1$ plasma. Variability did not exceed $15 \%$. Results are expressed as $\mu$ g equivalent bovine PTH/1 plasma. AP activity was analysed according to Bessey et al. (1946) and expressed as Bessey-Lowry units/1 plasma (one unit corresponding to $1 \mathrm{mmol} p$-nitrophenyl phosphate hydrolysed $/ \mathrm{h}$ per 1 at $37^{\circ}$ ).

Ca balance. A $10 \mathrm{~d} \mathrm{Ca}$ balance was carried out on four pigs of each group over the 2 weeks just before slaughter. Pigs were individually housed in appropriate cages.

Statistical analysis. Student's $t$ test was used to compare two means, studentized range $\mathrm{Q}$ test (Newman-Keuls including $\mathrm{Chi}^{2}$ test) for multiple-mean comparison and in some cases paired $t$ test for plasma value increases or decreases (Snedecor \& Cochran, 1971).

\section{RESULTS}

\section{Plasma kinetics (Table 2)}

Inorganic $P$. Plasma $P$ levels decreased in both groups until $4 \mathrm{~d}$ after the animals had been placed on the experimental $(+D$ or $-D)$ diets. However, this decrease was less marked in $+D$ pigs since, at day 4 , the plasma $P$ level of this group was significantly higher than that in the $-D$ group. Thereafter, plasma $P$ significantly increased in $+D$ pigs, reaching a maximum by 2 weeks with no further significant increase, while it remained low in $-D$ pigs. The difference between $-D$ and $+D$ values increased throughout the experimental period. The values for $+\mathrm{D}$ pigs were 30,40 and $50 \%$ greater than the corresponding $-\mathrm{D}$ values on day 4 and weeks 2 and 5 respectively.

$\mathrm{Ca}$. Plasma $\mathrm{Ca}$ concentrations initially decreased in both groups of animals until vitamin $D$ supplementation. They then increased throughout the experiment in the $+D$ group while remaining low and stable in $-D$ group. The value at slaughter did not differ from the initial value in the $+D$ pigs. Thus, vitamin $\mathrm{D}$ supplementation restored calcaemia to normal.

$A P$. Plasma AP activity significantly decreased after 2 weeks on the vitamin-Dsupplemented diet, but remained high in $-D$ pigs. At slaughter, $-D$ AP values were threefold higher than the corresponding $+\mathrm{D}$ values and approximately twice that of the 2-week - D values.

Vitamin D metabolites. Plasma 25-OHD levels increased (seven times the initial value) rapidly and markedly after $4 \mathrm{~d}$ of vitamin $\mathrm{D}$ supplementation with no further significant increase. They significantly decrease (by $77 \%$ of initial value on day 4 ) to reach negligible values in $-D$ pigs. The level at slaughter was below the detection limit in many of the $-D$ animals, thus confirming the vitamin-D-deficient status of the $-\mathrm{D}$ group.

Plasma $1,25(\mathrm{OH})_{2} \mathrm{D}_{3}$ increased progressively in $+\mathrm{D}$ pigs since maximal values were observed by 2 weeks. The percentage initial value increases were respectively 80,180 and 170 (rounded values) by day 4 and weeks 2 and 5 following feeding of the $+D$ diet. Thus, these increments were relatively less striking than those obtained for 25-OHD: sevenfold, 
Table 2. Plasma calcium, inorganic phosphorus, alkaline phosphatase (EC 3.1.3.1; AP; Bessey-Lowry units/l) vitamin $D$ metabolites and parathyroid hormone $(P T H)$ of pigs fed on a phytate- $P$ diet with $(+D)$ or without $(-D)$ vitamin $D_{3}$

(Results are expressed as means with their standard errors for fourteen ( 2 weeks before starting vitamin D supplementation) or seven ( $4 \mathrm{~d}, 2$ and 5 weeks after starting vitamin D supplementation) pigs per group)

\begin{tabular}{|c|c|c|c|c|c|c|c|}
\hline \multirow{2}{*}{$\begin{array}{l}\text { Vitamin D } \\
\text { supplementation... }\end{array}$} & \multirow{2}{*}{$\begin{array}{l}2 \text { weeks before } \\
\quad \text { (time } 0)\end{array}$} & \multicolumn{2}{|c|}{$4 \mathrm{~d}$ after } & \multicolumn{2}{|c|}{2 weeks after } & \multicolumn{2}{|c|}{5 weeks after } \\
\hline & & $+\mathrm{D}$ & $-\mathrm{D}$ & $+\mathrm{D}$ & $-\mathrm{D}$ & $+\mathrm{D}$ & $-\mathrm{D}$ \\
\hline \multicolumn{8}{|l|}{$\mathrm{Ca}(\mathrm{mmol} / \mathrm{l})$} \\
\hline Mean & $3 \cdot 0$ & $2.5 \dagger$ & $2 \cdot 2^{* * \dagger}$ & $2 \cdot 7+t$ & $2 \cdot 1^{* * \dagger} \dagger$ & $2 \cdot 9 \ddagger$ & $2 \cdot 0^{* *} \dagger$ \\
\hline $\mathrm{SE}$ & 0.04 & $0 \cdot 07$ & 0.04 & 0.05 & 0.07 & 0.08 & 0.04 \\
\hline \multicolumn{8}{|l|}{$\mathrm{P}(\mathrm{mmol} / \mathrm{l})$} \\
\hline Mean & 1.9 & $1.4 \uparrow$ & $1 \cdot 1^{* *+}$ & $2 \cdot 2+\ddagger$ & $1 \cdot 6^{* *}$ & $2-4 \dagger$ & $1 \cdot 6^{* *}$ \\
\hline SE & $0 \cdot 1$ & $0 \cdot 1$ & $0 \cdot 1$ & 0.2 & $0 \cdot 2$ & $0 \cdot 2$ & $0 \cdot 1$ \\
\hline \multicolumn{8}{|l|}{ AP (units/l) } \\
\hline Mean & $6 \cdot 3$ & $5 \cdot 1$ & $5 \cdot 2$ & $2 \cdot 6+t$ & $4 \cdot 3^{* * \dagger}$ & $2.9 \dagger$ & $9 \cdot 1^{* *++}$ \\
\hline SE & $0 \cdot 2$ & $0 \cdot 4$ & 0.5 & 0.2 & $0 \cdot 6$ & $0 \cdot 2$ & $1 \cdot 0$ \\
\hline \multicolumn{8}{|l|}{ 25-OHD (nmol/1) } \\
\hline Mean & $4 \cdot 3$ & $29 \cdot 8 \uparrow$ & $1.0^{* * \dagger}$ & $38 \cdot 0 \dagger$ & $1 \cdot 3^{* * \dagger} \dagger$ & $42 \cdot 2 \dagger$ & $0.05^{* *} \dagger$ \\
\hline $\mathrm{SE}$ & $0 \cdot 3$ & 18.8 & 0.5 & $6 \cdot 0$ & $0 \cdot 8$ & $10 \cdot 3$ & 0.2 \\
\hline \multicolumn{8}{|l|}{$1,25(\mathrm{OH})_{2} \mathbf{D}_{3}(\mathrm{pmol} / 1)$} \\
\hline Mean & $47 \cdot 6$ & $85.0 \dagger$ & $15 \cdot 6^{* *}+$ & $132 \cdot 5 t t$ & $15 \cdot 9 * * \dagger$ & $126 \cdot 6 \dagger$ & $13 \cdot 0^{* *}+$ \\
\hline SE & $2 \cdot 6$ & $3 \cdot 5$ & $2 \cdot 2$ & 14.9 & $2 \cdot 9$ & $12 \cdot 5$ & 1.7 \\
\hline \multicolumn{8}{|l|}{ PTH $(\mu \mathrm{g} / 1)$} \\
\hline Mean & $1 \cdot 1$ & $0.8 \dagger$ & $1 \cdot 1 * *$ & 0.9 & $1 \cdot 4^{* *}$ & $0.8 \dagger$ & $1 \cdot 7^{* *}$ \\
\hline $\mathrm{SE}$ & $0 \cdot 1$ & 0.05 & $0 \cdot 1$ & 0.05 & $0 \cdot 1$ & $0 \cdot 1$ & $0 \cdot 3$ \\
\hline
\end{tabular}

25-OHD, 25-hydroxycholecalciferol; $1,25(\mathrm{OH})_{2} \mathrm{D}_{3}, 1,25$-dihydroxycholecalciferol.

** Mean values for $+\mathrm{D}$ were significantly different $(P<0.01)$ from those for $-\mathrm{D}$ at the same time period (Student's $t$ test).

$\dagger$ Mean values were significantly different $(P<0.05)$ from those for $\dagger$ initial (time 0$)$ values or $\ddagger$ the immediately preceding value within the same group (i.e. $+\mathrm{D}$ or $-\mathrm{D}$ ). For $\mathrm{Ca}$, inorganic $\mathrm{P}$ and $\mathrm{AP}$, multiple mean comparison (MMC) test was used. For 25-OHD, 1,25(OH) ${ }_{2} \mathrm{D}_{3}$ and PTH, chi ${ }^{2}$ values prevented the use of the MMC test, therefore paired $t$ test was used.

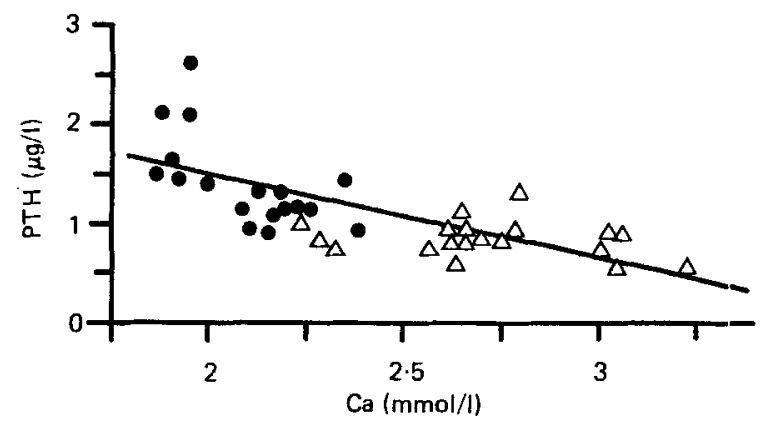

Fig. 1. Relation between plasma calcium and parathyroid hormone (PTH) of pigs fed on a phytatephosphorus diet with $(+\mathrm{D} ; \triangle)$ or without $(-\mathrm{D} ; 0)$ vitamin $\mathrm{D}_{3}, y=3 \cdot 17-0 \cdot 86 x, r-0 \cdot 72, P<0.01$.

ninefold and tenfold respectively by day 4 and weeks 2 and 5 . In $-\mathrm{D}$ pigs, plasma $1,25(\mathrm{OH})_{2} \mathrm{D}_{3}$ fell significantly by day 4 with no further significant decrease.

$P T H$. The experimental $+\mathrm{D}$ and $-\mathrm{D}$ diets significantly modified plasma PTH levels. They were elevated in $-\mathrm{D}$ pigs and lowered in $+\mathrm{D}$ pigs. Compared with initial values, the first significant decrease occurred by day 4 with no further decrease in $+D$ pigs, while 


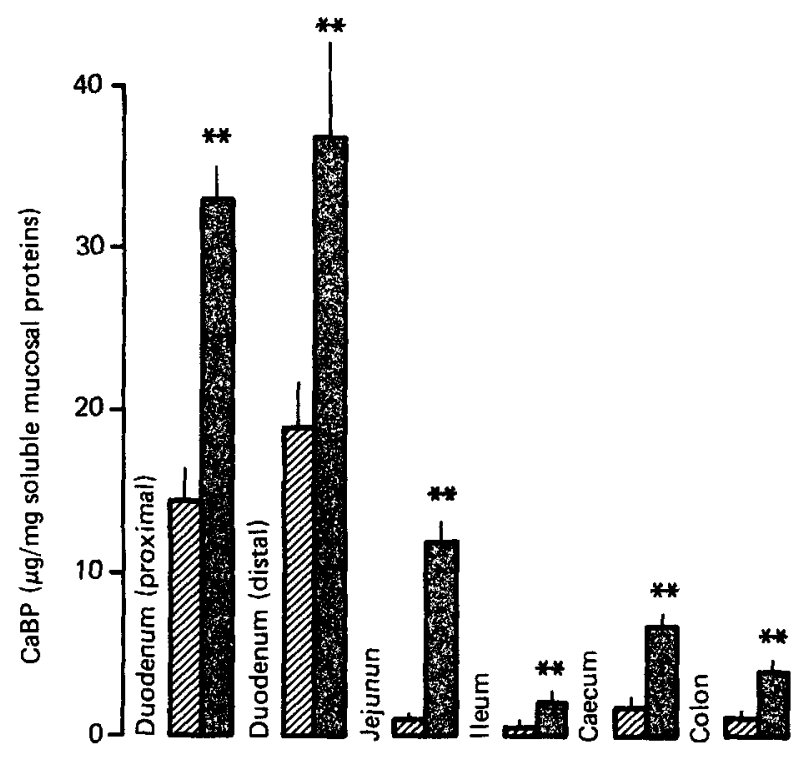

Fig. 2. Intestinal calcium-binding protein (CaBP) concentrations of pigs fed on a phytate-phosphorus diet with ( $+\mathrm{D}$; 圈) or without ( $-\mathrm{D}$ 熘) vitamin $\mathrm{D}_{3}$. Results are expressed as means with their standard errors represented by vertical bars from seven pigs per group. ${ }^{* *} P<0 \cdot 01,+D v .-D$, Student's $t$ test.

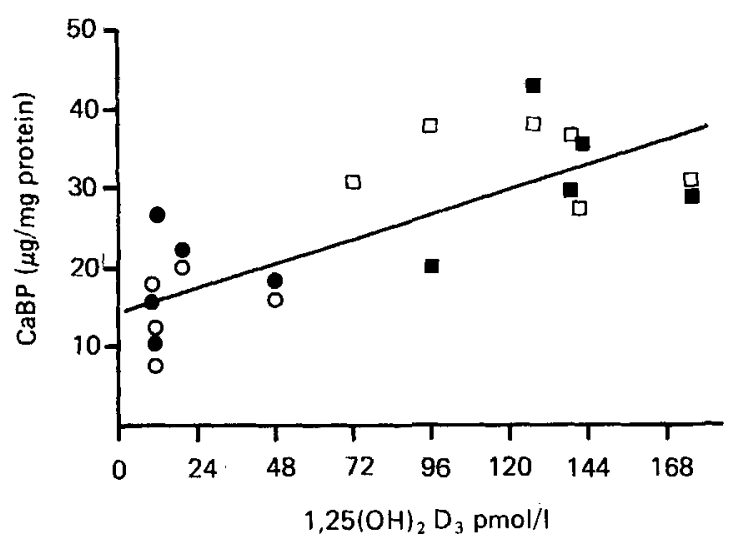

Fig. 3. Relation between pooled duodenal (proximal $\mathrm{O}, \square$; distal $\mathbf{O}$ ) calcium-binding protein (CaBP) and plasma 1,25-dihydroxycholecalciferol $\left(1,25(\mathrm{OH})_{2} \mathrm{D}_{3}\right)$ in pigs fed on a phytate-phosphorus diet with $(+D ; \square, \square)$ or without $(-D ; O, O)$ vitamin $D_{3}$. Two samples were unavailable for assay in each of the $-\mathrm{D}$ groups and the $+\mathrm{D}$ distal duodenum, one from the $+\mathrm{D}$ proximal duodenum was not assayed. $y=0.12 x+15 \cdot 4, r 0 \cdot 76, P<0 \cdot 01$.

in -D pigs, increases appeared by weeks 2 and 5 but these were not significant. However, compared with $+\mathrm{D}$ values, plasma PTH levels were systematically and significantly greater in $-D$ pigs with a rather important twofold difference at slaughter. In addition, a significant negative relation between plasma $\mathrm{Ca}$ and PTH was found in both groups for the values over the final 5-week period (Fig. 1).

$\mathrm{CaBP}$ (Fig. 2). Mucosal CaBP contents were markedly increased by vitamin $\mathrm{D}$ supplementation along the whole intestine. The relative effect was greater in the jejunum (twelvefold), 


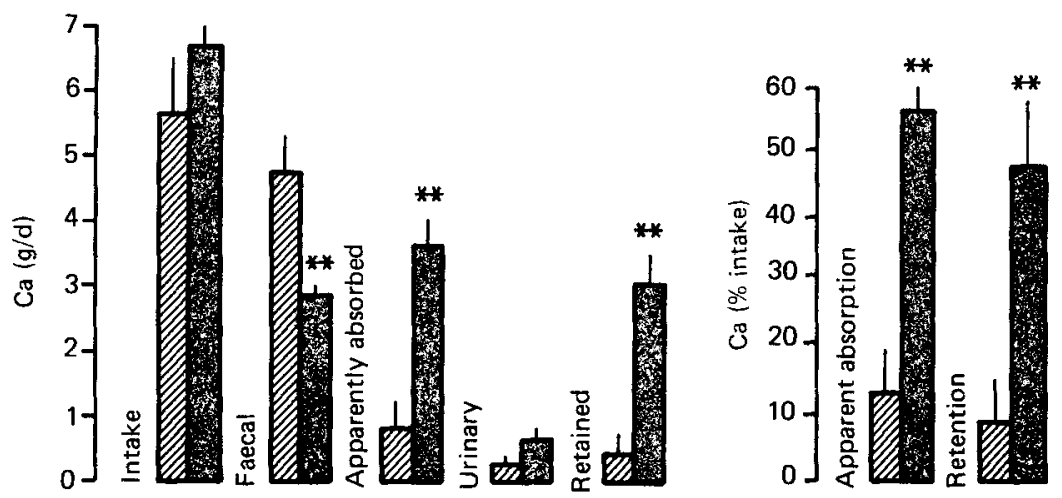

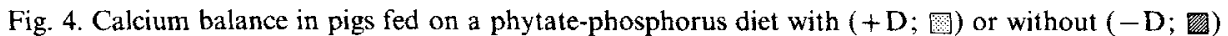
vitamin $D_{3}$. Results are expressed as means with their standard errors represented by vertical bars from four pigs per group. ${ }^{* *} P<0.01,+\mathrm{D} v$. $-\mathrm{D}$, Student's $t$ test.

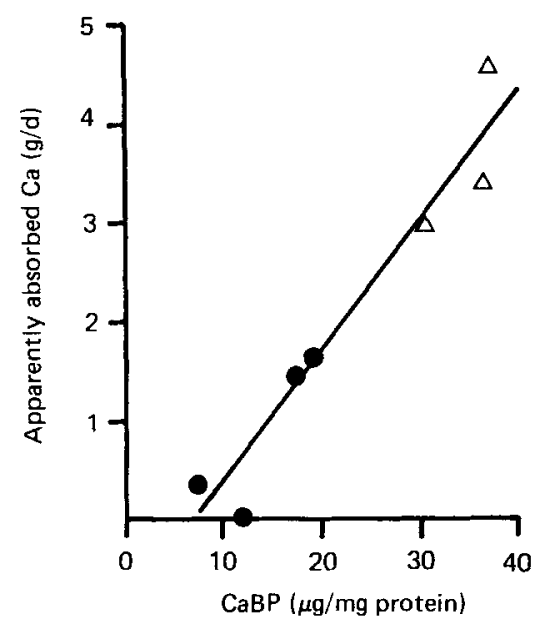

Fig. 5. Relation between proximal duodenal calcium-binding protein (CaBP) and apparently absorbed $\mathrm{Ca}$ in pigs fed on a phytate-phosphorus diet with $(+\mathrm{D} ; \triangle)$ or without $(-\mathrm{D} ; O)$ vitamin $\mathrm{D}_{3}$. $y=0.13 x-0.98, r 0.96, P<0 \cdot 01$.

ileum (fourfold), caecum (sevenfold) and colon (fourfold) than in the proximal or distal duodenum (twofold, $+\mathrm{D}$ v. $-\mathrm{D}$ ). Proximal and distal duodenal CaBP contents were also much greater than those of the more distal segments whatever the diet. The jejunal values were greater than those of the more distal intestinal segments in $+\mathrm{D}$ pigs only and they were not negligible when compared with duodenal values (jejunum 12.5 (SE 1.2) $v$. distal duodenum $37 \cdot 1$ (SE 6) $\mu \mathrm{g} / \mathrm{mg}$ protein). This was not the case in $-\mathrm{D}$ pigs where most of the intestinal values, with the exception of the duodenum, were negligible (from 0.5 to $1 \mu \mathrm{g} / \mathrm{mg}$ protein). A significant relation between plasma $1,25(\mathrm{OH})_{2} \mathrm{D}_{3}$ (slaughter values) and duodenal CaBP (both segments pooled) was also found for both groups of pigs (Fig. 3).

Ca balance (Fig. 4). The vitamin D supplementation dramatically improved apparent Ca absorption and retention (expressed as a percentage of intake or daily amount). These were about four and six times greater respectively, than those observed in non-supplemented pigs. Calciuria was high and comparable for both groups when expressed as daily amounts $(-D$ $0.4(\mathrm{SE} 0.1) v .+\mathrm{D} 0.6(\mathrm{SE} 0.2) \mathrm{g} / \mathrm{d})$ or percentage intake (-D $6(\mathrm{SE} 1.7),+\mathrm{D} 9.5$ (SE 3); 
$P>0 \cdot 10$ ). However, when expressed as relative to apparently absorbed $\mathrm{Ca}$, it was greater in $-\mathrm{D}$ than in $+\mathrm{D}$ pigs $(-\mathrm{D} 0.37$ (SE 0.01$) v .+\mathrm{D} 0.18$ (SE 0.07); $P<0.05$ ). A significant and close relation was found between proximal duodenal CaBP content and apparently absorbed Ca for both groups (Fig. 5).

\section{DISCUSSION}

Vitamin $\mathrm{D}$ treatment produced a twofold increase ( $4 \mathrm{~d} v$. initial values) in circulating $1,25(\mathrm{OH})_{2} \mathrm{D}_{3}$ within $4 \mathrm{~d}$. At the end of the same period $(4 \mathrm{~d})$ there was also a significant difference between the plasma $P$ of $+D$ and $-D$ pigs. This could be interpreted as the initial effect of vitamin $\mathrm{D}$ on $\mathrm{P}$ absorption since this vitamin markedly enhances phytate-P availability in pigs (Fontaine et al. 1985). Nevertheless, 2 weeks were necessary for plasma $\mathrm{P}$ to become significantly greater than initial values, corresponding to a threefold rise of $1,25(\mathrm{OH})_{2} \mathrm{D}_{3}$ (2-week $v$, initial values). Similar results were obtained by Engstrom et al. (1984) working on vitamin D-depleted but not P-depleted pigs given approximately the same amount of vitamin $\mathrm{D}_{3}(25 \mu \mathrm{g} / \mathrm{d})$. In the present study the plasma $\mathrm{P}$ of $+\mathrm{D}$ pigs increased from 60 to $75 \mathrm{mg} / 1$ (from 1.9 to $2.4 \mathrm{mmol} / \mathrm{l}$ ) while that in the vitamin-D-fed pigs in the study of Engstrom et al. (1984) increased from 59 to $78 \mathrm{mg} / \mathrm{l}$ over a similar period. The vitamin-D-deficient pigs studied by Engstrom et al. (1984) developed hyperphosphataemia while the vitamin-D-deficient pigs in the present study became hypophosphataemic (Table 2) although they received the same amounts of total $P(5-6 \mathrm{~g} / \mathrm{kg})$. The difference is probably the consequence of the two kinds of $\mathrm{P}$ given, since Engstrom et al. (1984) provided inorganic $\mathrm{P}\left(\mathrm{CaHPO}_{4}\right)$ instead of phytate- $\mathrm{P}$, which is known to cause hypophosphataemia and other signs of $\mathrm{P}$ deficiency (Pointillart et al. 1984, 1985; Fontaine et al. 1985). Such a $P$ deficiency will stimulate renal $1,25(\mathrm{OH})_{2} \mathrm{D}$ production via $1-\alpha$-hydroxylase as demonstrated in P-depleted pigs by Engstrom et al. (1985). However, the hypophosphataemia observed by Engstrom et al. (1985) $(1.2 \mathrm{mmol} / \mathrm{l})$ was much more acute than that of our pigs $(1.6 \mathrm{mmol} / \mathrm{l}$ at slaughter $)$ probably because their P-deficient diet $(0.85 \mathrm{~g} \mathrm{P} / \mathrm{kg}$ diet $)$ caused a greater $\mathrm{P}$ deficiency than the phytate-P diet which contained a normal amount of total $\mathrm{P}(5.8 \mathrm{~g} / \mathrm{kg})$. This could also explain the difference between $1,25(\mathrm{OH})_{2} \mathrm{D}_{3}$ values $(1100 \mathrm{pmol} / \mathrm{l})$ reported by these authors after 6 weeks of $P$ deficiency and our final values for the $+D$ phytate-P diet (Table 2).

The time-course of the vitamin D effect on plasma Ca was much slower than its effect on plasma $P$, since it returned to its initial value only after 5 weeks. Littledike et al. (1976) found a prompt reversal of the hypocalcaemia after $12 \mathrm{~d}$ of vitamin $\mathrm{D}_{3}(25 \mu \mathrm{g} / \mathrm{d})$ supplementation in pigs which were only vitamin-D-deficient. However, phytate-P diets decrease calcaemia (Pointillart et al. 1984, 1985) in pigs and thus could contribute to the delayed normalization of plasma $\mathrm{Ca}$. Both hypophosphataemia and hypocalcaemia could also result from simultaneous $\mathrm{Ca}$ and $\mathrm{P}$ unavailability of phytate-P diets because formation of unavailable $\mathrm{Ca}$-phytate takes place in the digestive tract as indicated by our previous findings on faecal $\mathrm{Ca}$ and $\mathrm{P}$ (Pointillart et al. 1985). Even if the phytate-based diets are responsible for the reduction in digestible $P$, and consequently for the phosphataemia, vitamin D deficiency itself may, in pigs, cause hyperphosphataemia (Engstrom et al. 1984). This would help to explain the tendency for the plasma $P$ levels to rise, often between $4 \mathrm{~d}$ and 2 weeks (and remain stable until the end of the experimental period) (Table 2) in pigs given no vitamin $\mathrm{D}$ supplement. In these same pigs the extreme vitamin $\mathrm{D}$ deficiency, which was confirmed by the low plasma $25-\mathrm{OHD}$ and $1,25(\mathrm{OH})_{2} \mathrm{D}$, values would make it impossible for the metabolism to be stimulated by lack of $P$ as has been suggested (Anon., 1974) and recently confirmed in pigs (Engstrom et al. 1985; Fox \& Ross, 1985). We ourselves have confirmed this in our earlier experiments on pigs fed on a diet containing phytate as the major form of $\mathrm{P}$ (Pointillart et al. 1984, 1985). 
Vitamin $\mathrm{D}_{3}$ supplementation increased mucosal CaBP contents along the whole intestine and dramatically enhanced $\mathrm{Ca}$ absorption. Moreover the significant correlations found between duodenal $\mathrm{CaBP}$ and apparently absorbed $\mathrm{Ca}$ and between duodenal $\mathrm{CaBP}$ and circulating $1,25(\mathrm{OH})_{2} \mathrm{D}_{3}$ suggest that vitamin $\mathrm{D}$ repletion leads to increased Ca absorption and a parallel increase in intestinal CaBP concentration. These responses are further stimulated by the secondary $P$ deficiency resulting from the high-phytate intake. The elevated vitamin-D-dependent $\mathrm{Ca}$ absorption, coupled with increased intestinal $\mathrm{CaBP}$, has also been shown in P-deficient rats (Thomasset et al. 1976), birds (Rosenberg et al. 1983; Bar \& Hurtwitz, 1984; Sommerville et al. 1985a) and pigs (Fox et al. 1978). The results are also in agreement with those previously obtained in pigs fed on phytate-rich diets without vitamin D supplement (Pointillart et al. 1985) and with the findings reported for vitamin-D-deficient rats (Wasserman et al. 1974) which was confirmed in pigs (Thomasset et al. 1979) treated with vitamin D. The increased CaBP contents of distal intestine, especially jejunum, caecum and colon, also demonstrate that these regions are able to respond to $1,25(\mathrm{OH})_{2} \mathrm{D}_{3}$ as was observed recently in rats (Perret et al. 1985). There is, thus, considerable support for the hypothesis that intestinal CaBP can play an important role in Ca absorption.

The increased $\mathrm{Ca}$ retention by $+\mathrm{D}$ pigs can lead to better bone mineralization, as previously described (Fontaine et al. 1985). Both vitamin D and $P$ deficiencies may increase plasma AP activity in pigs (Pointillart et al. 1984, 1985; Engstrom et al. 1985). Thus, simultaneous vitamin $\mathrm{D}$ and $\mathrm{P}$ deficiencies may have a synergistic effect on plasma AP since its final value in the $-D$ group was 1.5 the initial value and three times the $+D$ group final value.

Plasma PTH concentrations rapidly decreased in the $+\mathrm{D}$ group. They were invariably greater in the $-\mathrm{D}$ pigs than in the $+\mathrm{D}$ pigs. This is in agreement with the PTH rises found in pigs with hereditary vitamin-D-dependent rickets (Wilke et al. 1979), with simultaneous $\mathrm{P}$ and vitamin D deficiency (Pointillart et al. 1985) or with dietary vitamin-D-deficiency alone (Pointillart et al. 1978). However, the observation that $P$ deficiency alone decreases plasma PTH in vitamin-D-replete pigs (Sommerville et al. 1985b) may explain why the PTH increase of the $-\mathrm{D}$ group which was also P-deficient, was not significantly different from its initial value. Such an explanation is also supported by the unchanged PTH levels described for pigs fed on hypophosphataemic diets with no dietary vitamin D supplementation but normal circulating 25-OHD (50-125 nmol/l, Pointillart et al. 1984) levels as compared with the very low levels observed in $-\mathrm{D}$ pigs $(<1 \mathrm{nmol} / \mathrm{l})$. In addition, the significant negative correlation between plasma $\mathrm{Ca}$ and PTH levels suggests that hypocalcaemia was probably responsible for the PTH stimulation of the $-D$ pigs, while the absence of true hyperparathyroidism (maximal PTH increase was only $0.6 \mu \mathrm{g} / 1$, final $v$. initial values) was probably a consequence of the persistant hypophosphataemia resulting from dietary $P$ unavailability. Nevertheless, hypercalciuria persisted in the $+D$ pigs in spite of considerably enhanced $\mathrm{Ca}$ retention. Raising the dietary vitamin $\mathrm{D}$ of baby pigs from 0 to $25 \mu \mathrm{g} / \mathrm{kg}$ diet increases urinary Ca from 10 to $50 \mathrm{mg} / \mathrm{d}$ (Miller et al. 1965) but these values are negligible when expressed as a percentage of Ca intake $(1 \%)$ or compared with the 400 and $600 \mathrm{mg}$ urinary $\mathrm{Ca}$ excreted in the growing pigs fed on the phytate diet, with or without vitamin $\mathrm{D}$ respectively. Thus, it is suggested that vitamin $\mathrm{D}$ supplementation restored normal calcaemia and phosphataemia by increasing mineral absorption although some mineral disorders still persisted. Their persistence could be due to the phytate nature of the dietary P (Pointillart et al. 1984, 1985; Fontaine et al. 1985) or to the vitamin D treatment being too brief, or both. The second hypothesis is not supported by the normal circulating levels of $1,25(\mathrm{OH})_{2} \mathrm{D}_{3}(127-132 v \cdot 140-160 \mathrm{pmol} / 1$ in normal growing pigs, $\mathrm{De}$ Vernejoul et al. 1984) and the normal 25-OHD (30-42 nmol/1 v. normal pigs $55 \mathrm{nmol} / 1$, 
Thomasset et al. 1979; 32-82 nmol/1, Engstrom et al. 1985). Thus, the secondary P deficiency could be an explanation for the hypercalciuria. The rise in urinary $\mathrm{Ca}$, in terms of percentage $\mathrm{Ca}$ absorbed, found in the $-\mathrm{D}$ pigs supports this hypothesis. This persistent hypercalciuria suggests that mineral metabolism was still affected by the phytic nature of the dietary $\mathrm{P}$ in spite of the normalized plasma $\mathrm{Ca}$ and $\mathrm{P}$ levels obtained with the vitamin $\mathrm{D}$ supplementation. This relation is supported by persistant hypophosphaturia (urinary P $50 \mathrm{mg} / \mathrm{d}$, Fontaine et al. 1985). Thus vitamin D treatment considerably enhances Ca utilization (the present results) and P utilization (Fontaine et al. 1985) of pigs fed on a phytate-P diet but did not completely overcome the negative effects of phytate feeding on mineral metabolism.

\section{REFERENCES}

Adams, J., Clemens, T. L. \& Holick, M. F. (1981). Journal of Chromatography 226, 198-201.

Anon. (1974). Nutrition Review 38, 247-249.

Bar, A. \& Hurtwitz, S. (1984). Poultry Science 63, 1975-1979.

Bessey, O., Lowry, O. \& Brock, M. J. (1946). Journal of Biological Chemistry 164, 321-329.

Bouillon, R., Van Baelen, H. \& De Moor, P. (1977). Journal of Clinical Endocrinology and Metabolism 45, $225-231$.

Chen, P. S., Toribara, T. Y. \& Warner, H. (1956). Analytical Chemistry 28, 1756-1758.

De Vernejoul, M. C., Pointillart, A., Cywiner Golenzer, C., Morieux, C., Bielakoff, J., Modrowski, D. \& Miravet, L. (1984), American Journal of Pathology 116, 377-384.

Engstrom, G. W., Horst, R. L., Reinhardt, T. A. \& Littledike, E. T. (1984). Journal of Nutrition 114, $119-126$.

Engstrom, G. W., Horst, R. L., Reinhardt, T. A. \& Littledike, E. T. (1985). Journal of Animal Science 60, $1005-1010$.

Fontaine, N., Fourdin, A. \& Pointillart, A. (1985). Reproduction, Nutrition, Développement 25, 717-727.

Fox, J., Pickard, D. W., Care, A. D. \& Murray, T. M. (1978). Journal of Endocrinology 78, 379-387.

Fox, J. \& Ross, R. (1985). Journal of Endocrinology 105, 169-173.

Littledike, E., Hughes, M., Haussler, M. \& Arnaud, S. (1976). Proceedings of the International Pig Veterinary Society Congress, Ames, Iowa.

Miller, E. R., Ullrey, D. E., Zutaut, C. L., Hoeffer, J. A. \& Luecke, R. W. (1965). Journal of Nutrition 85, $255-259$.

Perret, C., Desplan, C. \& Thomasset, M. (1985). European Journal of Biochemistry 150, 211-217.

Pointillart, A., Fontaine, N. \& Thomasset, M. (1984). Nutrition Reports International 29, 473-483.

Pointillart, A., Fontaine, N., Thomasset, M. \& Jay, M. E. (1985). Nutrition Reports International 32, $155-167$.

Pointillart, A., Garel, J. M. \& Guéguen, L. (1978). Annales de Biologie Animale, Biochimie, Biophysique 18, 167-174.

Preece, M. A., O’Riordan, J. L. H., Lawson, D. E. M. \& Kodicek, E. A. (1974). Clinica Chimica Acta 54, $235-242$.

Rosenberg, J., Ben-gal, I., Pines, M., Hurtwitz, S. \& Bar, A. (1983). Nutrition Reports International 28, $335-343$.

Sommerville, B. A., Blahos, J., Harvey, S., Chadwick, A. \& Spencer, G. S. G. (1985a). Hormone and Metabolic Research 17, 245-250.

Sommerville, B. A., Maunder, E., Ross, R., Care, A. D. \& Brown, R. C. (1985b). Hormone and Metabolic Research 17, 78-81.

Snedecor, G. \& Cochran, W. (1971). Méthodes Statistiques, pp. 100-107, 302-307. Paris: ACTA.

Thomasset, M., Cuisinier-Gleizes, P. \& Mathieu, H. (1976). Biomedicine 25, 345--349.

Thomasset, M., Pointillart, A., Cuisinier-Gleizes, P. \& Guéguen, L. (1979). Annales de Biologie animale, Biochimie, Biophysique 19, 769-773.

Wasserman, R., Taylor, A. \& Fullmer, C. (1974). Biochemical Society Special Publications 3, 55-74.

Wilke, R., Harmeyer, J., von Grabe, C., Hehrmann, R. \& Hesch, R. D. (1979). Acta Endocrinologica 92, $295-308$. 